\title{
IZIN USAHA PERTAMBANGAN (TIMAH) DALAM KAWASAN HUTAN YANG DI WILAYAH KUBU KECAMATAN TOBOALI KABUPATEN BANGKA SELATAN
}

\author{
Fransisca Chatharina Yulian ${ }^{1)}$, Elsi Kartika Sari' ${ }^{2)}$ \\ 1,2) Fakultas Hukum Universitas Trisakti)
}

Corresponding author : elsi.ks@trisakti.ac.id, fransiscayulian@gmail.com

\begin{abstract}
ABSTRAK
Di Indonesia banyak sekali sumber daya alam yang tidak dapat diperbaharui, sumber daya alam yang tidak dapat diperbaharui memiliki nilai ekonomi yang sangat tinggi jika dibandingkan dengan sumber daya alam yang dapat diperbaharui. Secara sederhana pertambangan, adalah suatu kegiatan yang dilakukan dengan penggalian ke dalam tanah (bumi) untuk mendapatkan sesuatu yang berupa hasil tambang (mineral, minyak, gas bumi, dan batubara). Dalam kegiatan pertambangan dapat memanfaatan tanah yang terdapat dalam Kawasan Hutan, pada prinsipnya harus sesuai dengan fungsi dan peruntukkannya, akan tetapi tidak tertutup kemungkinan penggunaannya yang menyimpang dengan fungsi dan peruntukkanya. Metode yang digunakan penelitian hukum normatif menggunakan data sekunder,diolah secara kualitatif menggunakan metode penarikan kesimpulan secara deduktif. Pertambangan kawasan hutan harus mempunyai Izin Pinjam Pakai Kawasan Hutan (IPPKH) sesuai Pasal 6 ayat (1) serta Pasal 7 PP No 24 Tahun 2010. Pertambangan timah dalam kawasan hutan di Kabupaten Bangka Selatan, diatur Peraturan Daerah Provinsi Kepulauan Bangka Belitung No 7 Tahun 2014 tentang Pengelolaan Pertambangan Mineral, untuk melakukan kegiatan pertambangan mineral timah harus memiliki Izin Usaha Pertambangan (IUP) yang dikeluarkan oleh Gubernur, dan harus memiliki Izin Penggunaan Kawasan Hutan. Apabila tidak memiliki naik Izin Usaha Pertambangan serta tidak ada IPPKH, dikenakan sanksi Pasal 158UU No. 4 Tahun 2009 hukuman kurungan penjara paling lama 10 (sepuluh) tahun dan denda paling banyak Rp. 10.000.000.000,00 (sepuluh miliar rupiah) jo Pasal 78 ayat (6) Undang-Undang Nomor 41 Tahun 1999 dikenakan sanksi pidana penjara paling lama 10 (sepuluh) tahun dan denda paling banyak Rp. 5.000.000.000,00 (lima miliar rupiah).
\end{abstract}

Kata Kunci: Hukum Pertambangan, Pertambangan Timah dalam Kawasan Hutan

\section{PENDAHULUAN}

Kekayaan alam yang ada di Indonesia adalah sumber daya mineralnya yang tersebar hampir di seluruh wilayah Indonesia yang mana sumber daya dikuasai oleh negara dan diselenggarakan oleh Pemerintah dan/atau Pemerintah Daerah. Semua bahan tambang itu dikausai oleh negara dan dimanfaatkan untuk seluruh bangsa Indonesia, berdasarkan kelima sila dalam Pancasila sebagai satu kesatuan 
bulat, adanya norma atau kaidah dalam ketentuan Pasal 33 Ayat (3) UUD 1945 "Bumi, air dan kekayaan alam yang terkandung didalamnya dikuasai oleh negara dan dipergunakan untuk sebesar-besarnya kemakmuran rakyat. ${ }^{1}$ Atas dasar hak menguasai dari Negara yang dimaksud dalam pasal 2, selanjutnya ditegaskan dalam pasal 8 UUPA yang menyebutkan diatur pengambilan kekayaan alam yang terkandung dalam bumi, air, dan ruang angkasa. Wewenang menguasai tersebut dipergunakan untuk mencapai sebesar-besarnya kemakmuran rakyat Indonesia dan pelaksanaanya dapat dikuasai Kepala Daerah dan masyarakat hukum adat. ${ }^{2}$

Penguasaan bahan galian tidak hanya menjadi monopoli pemerintah semata-mata, tetapi juga diberikan hak kepada orang maupun badan hukum untuk mengusahakan bahan galian sehingga hubungan hukum antara negara dengan orang perorangan ataupun badan hukum harus diatur sedemikian rupa agar mereka dapat mengusahakan bahan galian secara optimal, oleh karena itu dikeluarkan peraturan mengenai pertambangan diatur dalam Undang-Undang Nomor 4 Tahun 2009 tentang Pertambangan Mineral dan Batubara yang merupakan penggantti dari UU No. 11 Tahun 1967. Secara sederhana pertambangan dapat diartikan sebagai suatu kegiatan yang dilakukan dengan penggalian ke dalam tanah (bumi) untuk mendapatkan sesuatu yang berupa hasil tambang (mineral, batubara, minyak dan gas bumi).

Pengertian mengenai pertambangan lebih jelas dinyatakan dalam UU No 4 Tahun 2009 yaitu sebagian atau seluruh tahapan kegiatan dalam rangka penelitian, pengolahan, dan penguasahaan mineral atau batu bara yang meliputi kegiatan penyelidikan umum, eksplorasi, studi kelayakan konstruksi, penambangan, pengolahan dan pemurnian, pengangkutan dan penjualan, serta kegiatan pasca tambang. ${ }^{3}$

Dalam kegiatan pertambangan dapat memanfaatan tanah yang terdapat dalam Kawasan Hutan. Kawasan Hutan menurut Pasal 1 Angka 3 Undang-Undang Nomor 41 Tahun 1999 tentang Kehutanan, adalah wilayah tertentu yang ditunjuk dan/atau ditetapkan oleh pemerintah untuk dipertahankan keberadaanya sebagai hutan tetap. Dalam pasal 6 Undang-Undang Nomor 41 Tahun 1999 tentang Kehutanan, pemerintah menetapkan hutan berdasarkan fungsi pokok yaitu hutan konservasi, hutan lindung dan hutan produksi. Namun dalam Pasal 38 UndangUndang Nomor 41 Tahun 1999 tentang Kehutanan,

Kawasan Hutan yang dapat digunakan untuk kegiatan diluar kegiatan kehutanan seperti pertambangan hanya dapat di dalam kawasan hutan lindung dan hutan produksi. Kegiatan pertambangan dalam penggunaan kawasan hutan, pada prinsipnya harus sesuai dengan fungsi dan peruntukkannya, akan tetapi tidak tertutup kemungkinan penggunaannya yang menyimpang dengan fungsi dan peruntukkanya. Pemberian izin untuk penggunaan pertambangan dalam kawasan

\footnotetext{
${ }^{1}$ Otong Rosadi, Pertambangan Dan Kehutanan Dalam Perspektif Cita Hukum Pancasila Dialektika Hukum Dan Sosial,2012,Cetakan.1,h.4.

2 Ibid., ayat (3) dan ayat (4)

${ }^{3}$ Undang-Undang Nomor 4 Tahun 2009 Tentang Pertambangan Mineral dan Batubara, Pasal 1 Angka 1
} 
hutan dilakukan melalui pemberian izin pinjam pakai kawasan hutan sesuai dengan Pasal 6 ayat (1) Peraturan Pemerintah Nomor 24 tahun 2010 tentang Penggunaan Kawasan Hutan serta dalam Pasal 7 peraturan ini juga menyebutkan bahwa izin pinjam pakai kawasan hutan tersebut diberikan oleh Menteri berdasarkan permohonan namun tidak tertutup kemungkinan penggunaannya yang menyimpang dengan fungsi dan peruntukannya serta tidak mengikuti aturan hukum yang ada seperti dalam hal melakukan kegiatan pertambangan dalam kawasan hutan tanpa memiliki izin atau dapat disebut pertambangan ilegal. Berdasarkan uraian diatas maka penulis akan membahas tentang" Izin Usaha Pertambangan (Timah) dalam Kawasan Hutan yang di Wilayah Kubu, Kecamatan Toboali, Kabupaten Bangka Selatan.

\section{PEMBAHASAN}

Pertambangan batubara adalah pertambangan endapan karbon yang terdapat dibumi, termasuk bitumen padat, gambut, dan batuan aspal. Tidak seperti pada pertambangan mineral, untuk pertambangan batubara tidak dikenal adanya macam-macam penggolangan. Dewasa ini pelaksanaan kegiatan pertambangan yang dilakukan tidak hanya dilakukan oleh perusahaan, tetapi ada pula sebagian dari kegiatan usaha yang dilakukan oleh pihak perseorangan serta tidak hanya dilakukan dalam wilayah pertambangan yang telah disediakan namun juga dalam kawasan hutan dan pada waktu sekarang ini dalam kenyataannya baik perseorangan maupun perusahaan melakukan kegiatan penambangan tersebut dengan tidak memperhatikan aspek-aspek yang penting di dalamnya,

Pertambangan Mineral adalah pertambangan kumpulan mineral yang berupa bijih atau batuan, diluar panas bumi, minyak dan gas bumi, serta air tanah. Ada 4 (empat) golongan pertambangan mineral, yaitu:

1. Mineral Radioaktif, adalah mineral yang mengandung elemen uranium. Contohnya : radium, uranium, dan thorium.

2. Mineral Logam, adalah mineral yang tidak tembus pandang dan dapat menjadi pengahantar panas dan arus listrik. Contohnya: berilium, magnesium, kalium,emas, timah, perak.

3. Mineral Bukan Logam, Contohnya: intan, pasir kuarsa, yodium, dan batu gamping untuk semen.

4. Batuan, adalah benda keras dan padat yang berasala dari bumi bukan logam. Contohnya: marmer, tang serap, tanah liat, dan pasir laut.

Dalam melakukan kegiatan usaha pertambangan, orang perorangan atau badan hukum dalam melakukan kegiatan pertambangan harus dilakukan dalam Wilayah Pertambangan yang selanjutnya disebut WP. Berdasarkan Pasal 9 UndangUndang Nomor 4 Tahun 2009 disebutkan bahwa wilayah pertambangan sebagai bagian dari tata ruang nasional merupakan landasan bagi penetapan kegiatan pertambangan. 
Setiap kegiatan usaha pertambangan yang dilakukan dalam wilayah pertambangan Indonesia harus memiliki izin dari Negara dan setiap izin memiliki luas wilayah yang diberikan untuk melakukan kegiatan pertambangan. Adapun 3 bentuk izin yang diatur oleh Undang-undang No 4 tahun 2009 yaitu:

1. Izin Usaha Pertambangan (IUP), yaitu izin untuk melakukan usaha pertambangan.

2. Izin Usaha Pertambangan Rakyat (IPR), yaitu izin untuk melaksanakan usaha pertambangan dalam wilayah pertambangan rakyat dengan luas wilayah dan investasi terbatas.

3. Izin Usaha Pertambangan Khusus (IUPK), yaitu izin untuk melaksanakan usaha pertambangan di wilayah izin usaha pertambangan khusus.

Untuk memberikan izin baik itu IUP, IPR, atau IUPK kewenangan menerbitkan izin tersebut berada ditangan Menteri, Gubernur, Bupati / Walikota sesuai kewenangnnya.

Supaya mendapatkan izin pertambangan, pemohon harus memenuhi persyaratan administrasi, teknis lingkungan dan finansial. Untuk melakukan usaha petambangan diperlukan izin usaha pertambangan. Pemberian Izin Usaha Pertambangan (IUP) yang dikenal konsep Wilayah Pertambangan dijadikan landasan dalam penetapan kegiatan pertambangan.

IUP diberikan kepada badan usaha, koperasi dan perseorangan. Berdasarkan Pasal 36 ayat (1) dan (2) UU No. \$ Tahun 2009 Tentang Mineral dan Batubara: IUP terdiri atas dua tahap yakni:

1. IUP Eksplorasi meliputi kegiatan penyelidikan umum, eksplorasi, dan studi kelayakan.

2. IUP Operasi produksi meliputi kegiatan konstruksi, penambangan, pengolahan dan pemurnian, serta pengangkutan dan penjualan.

Izin Usaha Pertambangan diberikan oleh bupati/walikota apabila berada didalam wilayah kabupaten/kota, diberikan oleh gubernur apabila berada pada lintas wilayah kabupaten/kota dalam 1(satu) provinsi setelah mendapat rekomendasi bupati/walikota dan diberikan menteri apabila wilayah usaha pertambangan berada pada lintas wilayah provinsi setelah rekomendasi gubernur dan bupati/walikota. Izin Usaha Pertambangan diberikan kepadan Perseorangan, Koperasi.

Seiring dengan perkembangan kebijakan sektor kehutanan, penggunaan kawasan hutan juga mengalami peningkatan, terutama untuk pertambangan. Hal itu terlihat dari ada banyaknya sumber daya tambang dan mineral di dalam kawasan hutan sehingga menjadi permasalahan sendiri mengingat kewenangan pengelolaan sumberdaya tersebut berada pada sektor yang berbeda dengan peengelolaan sumberdaya hutan.

Kawasan Hutan adalah wilayah tertentu yang ditunjuk dan atau ditetapkan oleh pemerintah untuk dipertahankan keberadaannya sebagai hutan tetap. Dalam Pasal 
6 ayat (2) Undang-Undang Nomor 41 Tahun 1999 Tentang Kehutanan, pemerintah menetapkan hutan berdasarkan fungsi pokok yaitu:

1. Hutan Konservasi;

2. Hutan Lindung

3. Hutan Produksi.

Didalam Pasal 38 ayat (3) Undang-Undang nomor 41 Tahun 1999 tentang Kehutanan disebutkan secar jelas bahwa penggunaan kawasan hutan untuk kepentingan pertambangan dilakukan melalui pemberian izin pinjam pakai yang berdampak penting dan cakupan luas serta bernilai strategis dilakukan oleh Menteri atas persetujuan Dewan Perwakilan Rakyat. Walaupun dalam Pasal 38 ayat (1) Undang-Undang nomor 41 Tahun 1999 tentang Kehutanan membolehkan penggunaan kawasan hutan produksi dan hutan lindung untuk kepentingan pertambangan, namun ditentukan sebuah larangan dalam penggunaan kawasan hutan lindung dengan pola pertambangan terbuka.

Penggunaan kawasan hutan untuk kepentingan pertambangan dilakukan melalui pemberian izin pinjam pakai oleh Menteri Kehutanan dengan mempertimbangkan batasan luas dan jangka waktu serta kelestarian lingkungan. ${ }^{4}$ Penggunaan kawasan hutan untuk kegiatan pertambangan dilakukan dengan ketentuan: $^{5}$ Dalam kawasan hutan produksi dapat dilakukan: Penambangan dengan pola pertambangan terbuka;dan Penambangan dengan pola pertambangan bawah tanah.

Oleh karenanya pemerintah dalam hal ini telah mengeluarkan kebijakan penggunaan kawasan hutan sebagai upaya untuk mengatur pengelolaan sumber daya tambang dan energi di dalam kawasan hutan. Dalam kebijakan tersebut diharuskan setiap perseorangan maupun badan usaha yang akan menggunakan kawasan hutan untuk kepentingan di luar sektor kehutanan untuk mengajukan permohonan Izin Pinjam Pakai Kawasan Hutan (IPPKH) kepada Menteri kehutanan.

Pasal 6 UU No. 4 Tahun 2009 adanya kewenangan Pemerintah Pusat kepada Pemerintah Daerah dalam hal penyelenggaraan pengelolaan usaha pertambangan mineral dan batubara, disemua kabupaten Kepulauan Bangka Belitung diatur dalam Peraturan Daerah Provinsi Kepulauan Bangka Belitung Nomor 7 Tahun 2014 tentang Pengelolaan Pertambangan Mineral. Kegiatan pertambangan mineral termasuk pertambangan timah secara umum harus memiliki izin Usaha Pertambangan (IUP) yang selanjutnya kegiatan pertambangan tersebut dilakukan dalam Wilayah Izin Usaha Pertambangan (WIUP) yang telah ditetapkan pemerintah. Pasal 18 Peraturan Daerah Provinsi Kep. Bangka Belitung Nomor 7 Tahun 2014, WIUP itu sendiri didapatkan berdasarkan hasil lelang namun sebelum dilakukan lelang tersebut Gubernur dapat mengumumkan lelang WIUP tersebut secara terbuka kepada badan usaha, koperasi, dan perseorangan selama 3 (tiga) bulan sebelum pelaksanaan lelang dilaksanakan stelah mendapatkan rekomendasi

\footnotetext{
${ }^{4}$ Undang-Undang Nomor 41 Tahun 1999 tentang Kehutanan, Pasal 38 ayat (3)

${ }^{5}$ Peraturan pemerintah Nomor 24 Tahun 2010 Tentang Penggunaan Kawasan Hutan. Pasal 5 ayat (1)
} 
dari bupati/walikota. Apabila telah ditetapkannya WIUP tersebut, Gubernur telah dapat memberikan Izin Usaha Pertambangan (IUP) kepada pemohon yang akan melakukan kegiatan pertambangan tersebut

Pemegang IUP juga memiliki jangka waktu untuk melakukan penambangan berkaitan dengan pertambangan timah, maka untuk IUP Eksplorasi pertambangan mineral logam diberikan dalam jangka waktu paling lama 8 (delapan) tahun, ${ }^{6}$ sedangkan untuk IUP Operasi Produksi dalam jangka waktu paling lama 20 (dua puluh) tahun dan dapat diperpanjang 2 (dua) kali masing-masing 10 (sepuluh) tahun. $^{7}$

Melakukan kegiatan pertambangan dalam kawasan hutan harus memiliki Izin Usaha Pertambangan (IUP), serta berkaitan dengan adanya penggunaan kawasan hutan tersebut harus memiliki izin yaitu Izin Pinjam Pakai Kawasan Hutan (IPPKH), maka berdasakan Pasal 109 Peraturan Daerah Provinsi Kepulauan Bangka Belitung Nomor 7 Tahun 2014 jo Pasal 158 Undang-Undang Nomor 4 Tahun 2009 tentang Pertambangan Mineral dan Batubara bahwa apabila "Setiap orang yang melakukan usaha penambangan tanpa IUP, IPR atau IUPK sebagaimana dimaksud dalam Pasal 37, Pasal 40 ayat (3), Pasal 48, Pasal 67 ayat (1), Pasal 74 ayat (1) atau ayat (5) dipidana dengan pidana penjara paling banyak Rp10.000.000.000,00 (sepuluh miliar rupiah) ", serta dalam Pasal 168 Undang-Undang ini juga menyatakan pelaku tindak pidana ini juga dikenakan pidana tambahan berupa:

1. Perampasan barang yang digunakan dalam melakukan tindak pidana;

2. Perampasan keuntungan yang diperoleh dari tindak pidana; dan/atau

3. Kewajiban membayar biaya yang timbul akibat tindak pidana.

Apabila pelaku pertambangan melakukan kegiatan pertambangan dalam kawasan hutan tanpa izin pinjam pakai kawasan hutan (IPPKH) dalam UndangUndang Nomor 41 Tahun 1999 Tentang Kehutanan dalam Pasal 78 ayat (6) diatur mengenai sanksi pidana yaitu diancam dengan pidana penjara paling lama 10 (sepuluh) tahun dan denda paling banyak Rp. 5.000.000.000,00 (lima milyar rupiah). Apabila pelaku pertambangan melakukan kegiatan pertambangan dalam kawasan hutan tanpa izin pinjam pakai kawasan hutan (IPPKH) dalam Undang-Undang Nomor 41 Tahun 1999 Tentang Kehutanan dalam Pasal 78 ayat (6) diatur mengenai sanksi pidana yaitu diancam dengan pidana penjara paling lama 10 (sepuluh) tahun dan denda paling banyak Rp. 5.000.000.000,00 (lima milyar rupiah).

\section{KESIMPULAN}

Pemberian izin dan pengelolaan terhadap kegiatan pertambangan timah di Kabupaten Bangka Selatan diatur dalam Peraturan Daerah Provinsi Kepulauan Bangka Belitung Nomor 7 Tahun 2014 tentang Pengelolaan Pertambangan Mineral

\footnotetext{
${ }^{6}$ Peraturan Daerah Provinsi Kepulauan Bangka Belitung Nomor 7 Tahun 2014 tentang

Pengelolaan Pertambangan Mineral, Pasal 37 Ayat (1)

${ }^{7}$ Peraturan Daerah Provinsi Kepulauan Bangka Belitung Nomor 7 Tahun 2014 tentang

Pengelolaan Pertambangan Mineral, Pasal 40 Ayat (1)
} 
yang merupakan penerapan Pasal 6 UU No 4 Tahun 2009 mengenai kewenangan Pemerintah Pusat kepada Pemerintah Dearah. Dalam Pasal 31 Perda Kepulauan Bangka Belitung Nomor 7 Tahun 2014 untuk melakukan kegiatan pertambangan di Kepulauan Bangka Belitung harus mempunyai Izin Usaha Pertambangan (IUP), apabila pertambahan tersebut dilakukan di Kawasan Hutam harus memenuhi 78 Ayat (6) Undang-Undang Nomor 41 Tahun 1999 tentang Kehutanan harus memilikin Izin Pinjam Pakai Kawasan Hutan (IPPKH), apabila tidak memilikin Izin Usaha Pertambangan dan dilakukan di kawasan Hutan, akan dikenakan sanksi Pasal 158 dikenakan hukuman kurungan penjara paling lama 10 (sepuluh) tahun dan denda paling banyak Rp. 10.000.000.000,00 (sepuluh miliar rupiah) jo Pasal 78 ayat (6) Undang-Undang Nomor 41 Tahun 1999 tentang Kehutanan dapat dikenakan sanksi pidana penjara paling lama 10 (sepuluh) tahun dan denda paling banyak Rp. 5.000.000.000,00 (lima miliar rupiah).

\section{DAFTAR PUSTAKA}

1. Otong Rosadi, Pertambangan Dan Kehutanan Dalam Perspektif Cita Hukum Pancasila Dialektika Hukum Dan Sosial,2012,Cetakan.1,h.4.

2. Undang-Undang Nomor 4 Tahun 2009 tentang Pertambangan Mineral dan Batubara

3. Undang-Undang Nomor 41 Tahun 1999 tentang Kehutanan

4. Peraturan Pemerintah Nomor 24 Tahun 2010 tentang Penggunaan Kawasan Hutan

5. Peraturan Daerah Provinsi Kepulauan Bangka Belitung Nomor 7 Tahun 2014 tentang Pengelolaan Pertambangan Mineral. 